\title{
ECCENTRIC GROWTH BUT NO COMPRESSION WOOD IN A HORIZONTAL STEM OF CYCAS MICRONESICA (CYCADALES)
}

\author{
Jack B. Fisher ${ }^{*}$ and Thomas E. Marler ${ }^{2}$
}

\begin{abstract}
SUMMARY
A single 1.41-m-long trunk of Cycas micronesica K.D. Hill was found growing horizontally in natural habitat on the island of Guam. Transverse sections of the trunk showed enhancement of secondary vascular tissues on the lower side by the production of more arcs of accessory vascular cambia and more parenchyma as compared to the upper side. Xylem tracheids were similar in upper and lower sides. There was no evidence of compression wood tracheids as seen in conifers.
\end{abstract}

Key words: Compression wood, cycad, Cycas, reaction wood, tracheids, vascular cambium.

\section{INTRODUCTION}

The wood of cycads (Cycadales) consists of tracheids, wide rays, and much parenchyma and has been termed "manoxylic" to differentiate its soft structure from the "pycnoxylic" wood of conifers that has denser wood with narrow rays (Seward 1917). The differences in wood structure have been useful in separating the Cycadophytes from the Coniferophytes, especially in wood fossils (Gifford \& Foster 1988). Another distinctive feature is the presence of multiple vascular cylinders in the stems of Bowenia, Cycas, Encephalartos, Lepidozamia and Macrozamia (Norstog \& Nicholls 1997). Chamberlain (1935) reported that 14 cylinders of secondary xylem (each with associated phloem) occurred in a stem of Cycas pectinata $20 \mathrm{~cm}$ in diameter, and three cylinders in a 3-m-tall Cycas media plant. Each of these concentric rings of secondary vascular tissue appears to retain its separate vascular cambium, although there is little activity in the inner cambia (Terrazas 1991).

We are unaware of any published reports regarding variations in wood structure in normally vertical stems that are displaced to more horizontal orientations. Many other gymnosperms form reaction wood, called compression wood, on the lower side of a leaning stem in which tracheids of the secondary xylem are more lignified and rounder in transverse section than those on the upper side (Timell 1986). Westing (1965) noted that compression wood occurs in Coniferales, Ginkgoales and Taxales but "probably not in Cycadales". Neither reaction wood nor compression wood in cycads are mentioned

1) Fairchild Tropical Botanic Garden, 11935 Old Cutler Rd., Coral Gables, FL 33156 and Department of Biological Sciences, Florida International University, Miami, FL 33199, U. S. A. [E-mail: jfisher@fairchildgarden.org].

2) College of Natural and Applied Sciences, University of Guam, UOG Station, Mangilao, GU 96923, U.S.A. [E-mail: tmarler@uog9.uog.edu].

*) Author for correspondence. 

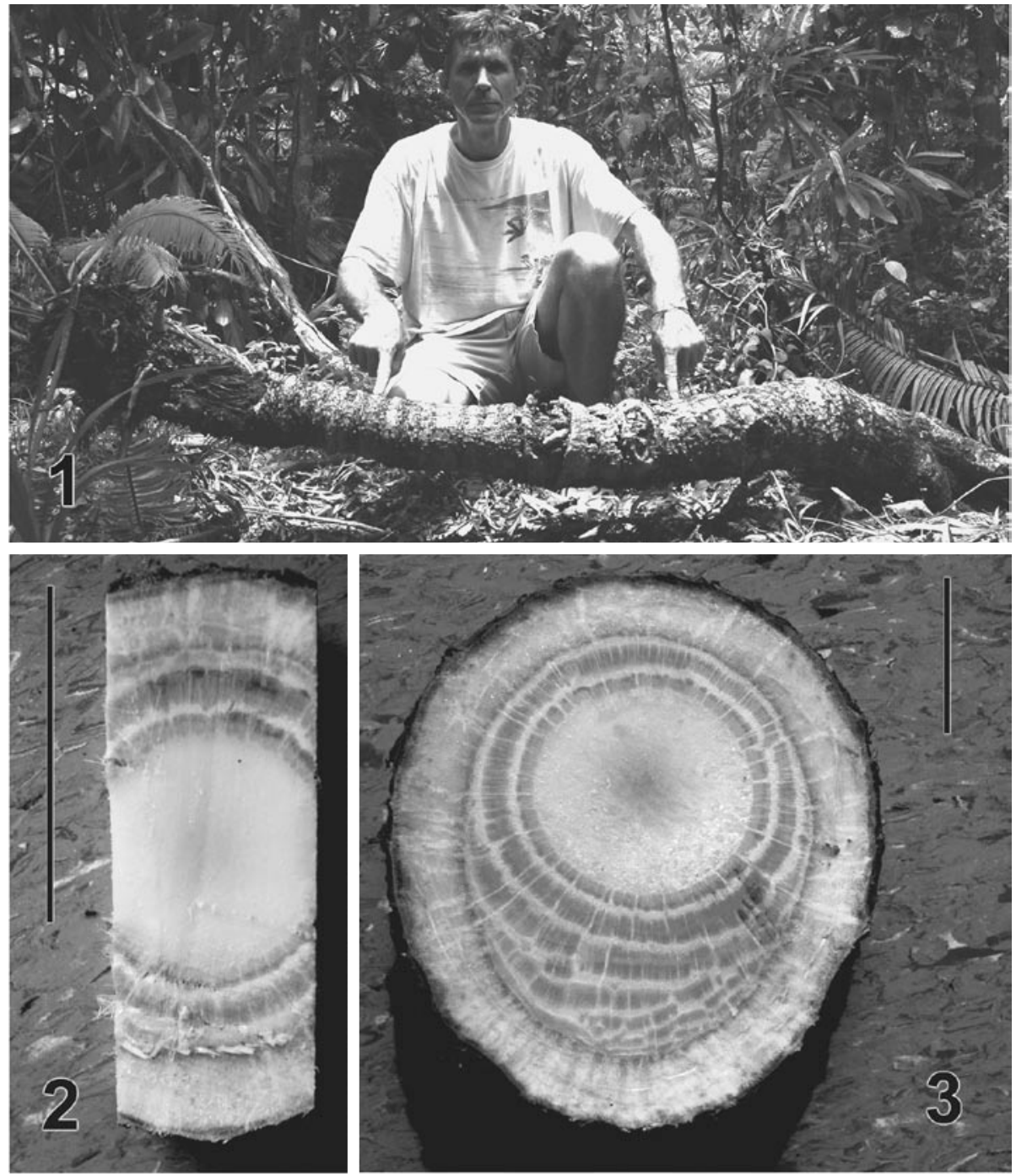

Fig. 1-3. - 1: Trunk of Cycas micronesica. Plant in forest; locations of the two samples are touched by T.E. Marler. - 2: Distal transverse sample; upper side to top of page. - 3: Proximal transverse sample; upper side to top of page. Note that 2 and 3 are not at the same magnification. - Scale lines $=50 \mathrm{~mm}$.

in Timell's (1986) comprehensive literature review or in Greguss' (1968) monograph on cycad anatomy.

Following Typhoon Paka an old tree of Cycas miconesica K.D. Hill was observed in a natural forest fragment on Guam as part of a larger phenological study (Hirsh \& Marler 2002). The tree had been growing nearly horizontal for many years. Recently, it became heavily infected with Asian cycad scale (Aulacaspis yasumatsui Takagi) and 
was approaching death. Previous experience with this insect indicated that the plant could not be saved. The trunk was cut at two levels for wood samples. This was an opportunity to see if this cycad forms reaction wood or other structural changes related to its reoriented position.

\section{MATERIALS AND METHODS}

The microsite is in the Andersen Air Force Base on the northwest tip of the island of Guam. Annual rainfall is c. $250 \mathrm{~cm}$ and seasonal. Precipitation exceeds evapotranspiration only from July through November. Calcareous soils overly coralline limestone (Ritidian-Rock outcrop complex) (Young 1988). This species flushes new leaves several times during the year in the shaded (50-75\% canopy cover) understory (Marler et al. 2005). Coordinates for our plant were: $13^{\circ} 38.61 \mathrm{~min}$ North; $144^{\circ} 51.35 \mathrm{~min}$ East. The collection was made using Guam Territorial Cutting Permit \# 2005-005.

The unbranched stem was $1.41 \mathrm{~m}$ in length from soil to base of leaf crown. The inclination of the stem at the two sampling sites was: distal $=88^{\circ}$ from vertical; proximal $=83^{\circ}$ from vertical (Fig. 1). Stem disks were cut from the stem and the central upper and lower sections were fixed in $70 \%$ ethanol. These pieces were later divided into small samples for sectioning.

Samples were either unembedded and cut with a sliding microtome or embedded in Paraplast m.pt. $56^{\circ} \mathrm{C}$ [Fisher Scientific, www.fishersci.com] and cut with a rotary microtome. Paraplast was removed and sections were dehydrated in an ethanolCitrisolv [Fisher Scientific, www.fishersci.com] series. The sections were stained with safranin and fast green combination, phloroglucinol: $\mathrm{HCl}$, or aqueous toluidine blue O. Images were taken with Nikon Coolpix 4500 and processed in Adobe Photoshop [www.adobe.com].

\section{RESULTS AND DISCUSSION}

The distal sample was nearly circular in transverse section with slightly more xylem in the outer (= third) vascular cylinder on the lower side. The upper side of the outer cylinder was visible but with little xylem (Fig. 2, Table 1). The older, proximal sample was eccentric with three to four additional arcs of vascular tissue on the lower side (Fig. 3, Table 1). The pith was wider than in the distal region. A general trend of increasing pith diameter has been reported in Cycas as a feature of establishment growth (Bork 1990; Terrazas 1991), but considerable variability was reported with upper regions of old trunks showing a reduced pith diameter (as seen in Table 1). The ratio of vertical to horizontal total stem diameter was $1: 3$ due to expanded cortex and vascular tissues on the lower side. The color of the xylem was cream-yellow without visible difference between upper and lower sides of the stem (Fig. 3).

Tissues on the upper and lower sides of the stem looked identical with respect to pigmentation, organization and general cell size. The arcs of darker or reddish wood, as seen in compression wood of conifers (Timell 1986) was not present. The xylem had tracheids aligned radially in rows one to four cells wide, alternating with rays with one to four parenchyma cells in width (Fig. 4). Parenchyma cells in all stem tissues, 
Table 1. Tissue thickness in a horizontal stem of Cycas micronesica at two positions from base.

\begin{tabular}{lcccc}
\hline & \multicolumn{4}{c}{ Position in stem } \\
\cline { 2 - 5 } & \multicolumn{3}{c}{ Distal } & \multicolumn{2}{c}{ Proximal } \\
& Upper & Lower & Upper & Lower \\
\cline { 2 - 5 } & $0.5-1$ & $0.5-1$ & $1-3$ & $1-3$ \\
& 13.7 & 16.4 & 13.8 & 17.3 \\
\hline Cork (mm) & 19.1 & 19.2 & 15.2 & 46.9 \\
Cortex (mm) & $2(-3)$ & 3 & $2(-3)$ & $6-7$ \\
Vascular tissues (mm) & 35 & - & 66.4 & - \\
Number of cylinders (mm) & 106 & - & 164 & - \\
Pith (mm) & 108 & - & 133 & - \\
Total vertical diameter (mm) & 1.027 & - & 1.180 & - \\
Total horizontal diameter (mm) & & & & \\
Ratio (vertical/horizontal) & &
\end{tabular}
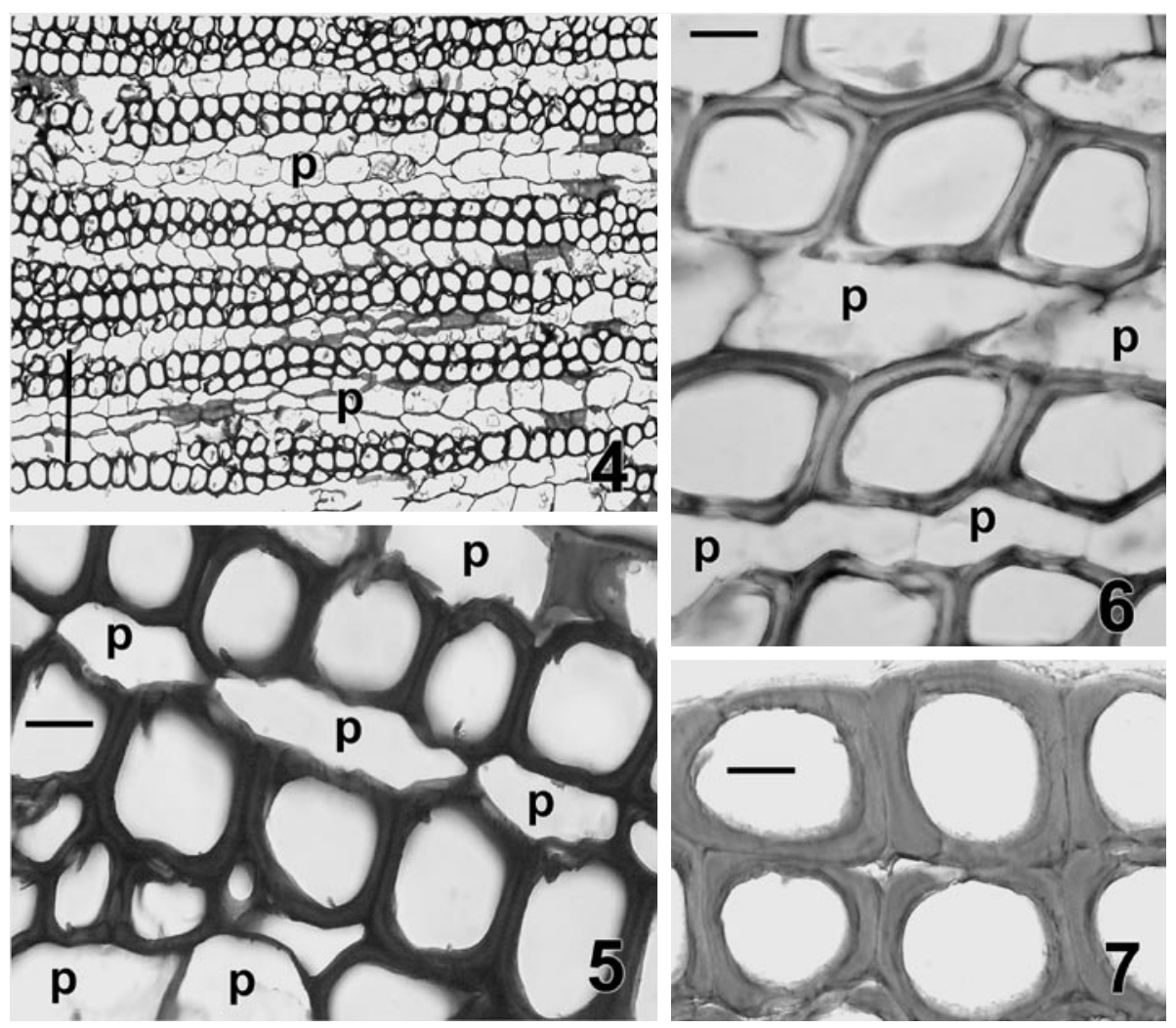

Fig. 4-7. Transverse 10- $\mu$ m-thick sections of Cycas micronesica; from lower side of the outer vascular cylinder of the proximal sample. -4 : Stained with toluidine blue; hydrated. -5 : Stained with toluidine blue; hydrated; edges of tracheid wall ripped. -6 : Stained with safranin and fast green; dehydrated. -7 : Stained with phloroglucinol and $\mathrm{HCl}$; hydrated. $-\mathrm{p}$ : parenchyma cells among thicker-walled tracheids. - Scale line of $4=200 \mu \mathrm{m}$, of $5-7=20 \mu \mathrm{m}$. 
including xylem, usually had many starch grains per cell (not well stained in Fig. 4-7). Tracheids were square to polygonal in transverse section. Lateral walls had circular bordered pitting. Xylem structure was fully consistent with the detailed description of other Cycas species by Greguss (1968).

The secondary wall did not show layering in light microscope views of the 10- $\mu \mathrm{m}$ thick sections (Fig. 5-7). Tracheid walls were thicker in hydrated, HCl-treated preparations (Fig. 7) than in either dehydrated (Fig. 6) or hydrated preparations without $\mathrm{HCl}$ treatment (Fig. 5). However, there was no consistent difference in transverse shape or wall thickness between upper and lower samples prepared in the same manner. The degree of lignification appeared to be uniform within one cell based on the intensity of phloroglucinol staining (Fig. 7), but safranin was taken up (or lost) irregularly by tracheid walls in the dehydrated preparations (Fig. 6). Circular shaped tracheids with intercellular spaces as found in some coniferous compression wood (Timell 1986) were not observed. The outer vascular cylinders on the lower side became disrupted by proliferation of ray parenchyma and irregular arcs of vascular cambium (Fig. 3). The more typical erect stems of Cycas species have concentric and complete vascular cylinders or rings (Greguss 1968; Terrazas 1991).

We conclude that $C$. micronesica produced reaction anatomy in the form of secondary growth promotion on the lower side of horizontal stems. There was an increase in the number of new accessory vascular cambia and the amount of secondary tissues produced on the lower side. Enhanced parenchyma production accompanied the vascular tissue. Coniferales, Ginkgoales, and Taxales also have greater cambial activity on the lower sides of branches and leaning trunks, although such increased wood production is associated with compression tracheids (Westing 1965; Timell 1986; Fahn 1990). This promotion of growth on the lower side is superficially similar to the eccentric growth in those few monocotyledons having secondary growth in which a single variant cambium produces more diffuse vascular bundles (more intervening parenchyma) and less lignified parenchyma on the lower side of horizontal stems (Fisher 1975). Although generally dicotyledons form more secondary xylem with tension fibers (= gelatinous fibers) on the upper side of leaning stems, many dicotyledons lack tension (or gelatinous) fibers and produce unique reaction wood on the lower side. In these examples, less parenchyma is formed than on the upper side (e.g., Entelea of the Tiliaceae illustrated in Philipson et al. 1971). However, while there was reaction anatomy in C. micronesica, there were no discernible changes in tracheid structure in Cycas that could be interpreted as compression wood tracheids.

\section{ACKNOWLEDGEMENTS}

We thank P. Barry Tomlinson for help in obtaining library material and comments on the manuscript.

\section{REFERENCES}

Bork, J. 1990. Developmental cycles in shoot growth of male Cycas circinalis. Amer. J. Bot. 77: 981-985.

Chamberlain, C. J. 1935. Gymnosperms: structure and evolution. University of Chicago Press, Chicago. [1966 reprint. Dover Publications, New York.] 
Fahn, A. 1990. Plant anatomy. Ed. 4. Pergamon Press, Oxford.

Fisher, J.B. 1975. Eccentric secondary growth in Cordyline and other Agavaceae (Monocotyledonae) and its correlation with auxin distribution. Amer. J. Bot. 62: 292-302.

Gifford, E.M. \& A.S. Foster. 1988. Morphology and evolution of vascular plants. Ed. 3. W.H. Freeman and Co., New York.

Greguss, P. 1968. Xylotomy of the living cycads. Akadémiai Kiadó, Budapest.

Hirsh, H. \& T. Marler. 2002. Damage and recovery of Cycas micronesica after Typhoon Paka. Biotropica 34: 598-602.

Marler, T.E., V. Lee \& C.A. Shaw. 2005. Spatial variation of steryl glucosides in Cycas micronesica plants: within- and among-plant sampling procedures. HortScience 40: 1607-1611.

Norstog, K. J. \& T. J. Nicholls. 1997. The biology of the cycads. Cornell University Press, Ithaca.

Philipson, W.R., J.M. Ward \& B.G. Butterfield. 1971. The vascular cambium: its development and activity. Chapman \& Hall, London.

Seward, A.C. 1917. Fossil plants, Vol. III. Cambridge University Press, London.

Terrazas, T. 1991. Origin and activity of successive cambia in Cycas (Cycadales). Amer. J. Bot. 78: $1335-1344$.

Timell, T.E. 1986. Compression wood in gymnosperms. Vol. 1-3. Springer-Verlag, New York. Westing, A.H. 1965. Formation and function of compression wood in gymnosperms. Bot. Rev. 31: 381-480.

Young, F. J. 1988. Soil survey of the territory of Guam. U.S. Dept. Agr. Soil Cons. Survey, Washington, D.C. 